Аніксєв O.I.,

Сировицький К.Г., Агапов М.O., Бойко А.О.

Харківський національний технічний університет сільського господарства ім. Петра Василенка

e-mail: anikeev55@ukr.net

\section{МЕТОДИКА ОБГРУНТУВАННЯ РАЦІОНАЛЬНОГО СКЛАДУ І ШВИДКІСНОГО РЕЖИМУ РОБОТИ МАШИННИХ АГРЕГАТІВ}

УДК 631.38 .001

Анікеєв О.І., Сировицький К.Г., Агапов М.О., Бойко А.О. «Методика обгрунтування раціонального складу і ивидкісного режиму роботи машинних агрегатів»

В статті наведено методику обтрунтування раціонального складу і швидкісних режимів роботи машинних агрегатів для виконання технологічних операцій при вирощуванні продукції рослинництва.

Висновок про правильність вибору того чи іншого складу агрегату необхідний з урахуванням маневрових характеристик трактора і кінематичних параметрів робочої машини. Значення коефічієнтів зчеплення ведучого апарату з трунтом та опору перекочування для різних агрофонів відіграє важливу роль у процесі вибору швидкісного режиму роботи, щзо в свою чергу покликано збільшити продуктивність, зменшити витрати палива та підвищити якість виконання технологічних операцій в рослинництві. Також науково-обтрунтований підхід до вибору складу агрегату дає можливість зменшити затрати прачі та підвищити техніко-економічну ефективність використання машинно-тракторних агрегатів. В багатьох випадках, швидкість, яка визначається по енергонасиченості трактора, не може бути реалізована внаслідок агротехнологічних або фізіологічних обмежень. Економічні обмеження швидкості машинного агрегату обумовлені зміною енерговитрат на виконання процесу, експлуатаційної надійності машин в складі агрегату, а також деяким погіршенням використання часу зміни. В кожному окремому випадку швидкісні режими роботи необхідно уточнювати з урахуванням фізико-механічних властивостей трунтів, стану поверхні поля, фаз розвитку рослин, вологості грунту і інших факторів які впливають на якість роботи.

Відповідність параметрів агрегату, пери за все виробничим умовам - $е$ передумовою високої продуктивності агрегату. Із збільшенням ширини захвату агрегату пропориійно підвищується його продуктивність, а для посівних машин, обприскувачів і ряду інших - підвищується якість виконання роботи, внаслідок зменшення площзі поля яка піддається дії ходових систем, зменшується кількість стикових міжрядь, поліпшуються умови технологічного обслуговування агрегату і скорочується кількість персоналу по його обслуговуванню.

Ключові слова: машинний агрегат, обтрунтування, оптимізачія, швидкісні режими, методика, продуктивність.

Аникеев А.И., Сыровицкий К.Г., Агапов М.А., Бойко А.А. «Методика обоснования рационального состава и скоростного режима работы машинных агрегатов"

В статье приведена методика обоснования рачионального состава и скоростных режимов работы машинных агрегатов для выполнения технологических операций при выращиивании продукции растениеводства.

Вывод о правильности выбора того или иного состава агрегата необходимо с учетом маневровых характеристик трактора и кинематических параметров рабочей машины. Значения коэффициентов сиепления ведущего аппарата с грунтом и сопротивления перекатывания для различных агрофонов играет важную роль в процессе выбора скоростного режима работы, что в свою очередь призвано увеличить производительность, уменьшить расход топлива и повысить качество выполнения технологических операчий в растениеводстве. Также научно обоснованный подход к выбору состава агрегата позволяет уменьшить затраты труда и повысить технико-экономическую эффективность использования машиннотракторных агрегатов. Во многих случаях, скорость, определяемая по энерго насыщенности трактора, не может быть реализована в результате агротехнологических или физиологических ограничений. Экономические ограничения скорости машинного агрегата обусловлены изменением энерго затрат на выполнение процесса, эксплуатационной надежности машин в составе агрегата, а также некоторым ухудшением использования времени смены. В каждом отдельном случае скоростные режимы работы необходимо уточнять с учетом физико-механических свойств грунтов, состояния поверхности поля, фаз развития растений, влажности почвы и других факторов влияющих на качество работы.

Соответствие параметров агрегата, прежде всего производственным условиям - является предпосылкой высокой производттельности агрегата. С увеличением иирины захвата агрегата пропорционально повышается его производительность, а для посевных машин, опрыскивателей и ряда других - повышается качество выполнения работы, вследствие уменьшения площади поля которая подвергается 
воздействию ходовых систем, уменьшается количество стыковых междурядий, улучшаются условия технологического обслуживания агрегата и сокращуается количество персонала по его обслуживанию.

Ключевые слова: машинный агрегат, обоснование, оптимизация, скоростные режимы, методика, производительность.

O. Anikeev, K. Sirovitskiy, M. Agapov, A. Boiko «Methodology of substantiation of rational composition and operation speed mode of machine units"

In the article the technique of substantiation of rational composition and speed modes of operation of machine aggregates for performance of technological operations in growing of crop production is presented.

The conclusion about the correct choice of a particular composition of the unit is necessary taking into account the maneuvering characteristics of the tractor and the kinematic parameters of the working machine. The value of the coupling coefficients of the leading machine with the soil and the rolling resistance for various agrophones play an important role in the selection of speed mode of operation, which in turn aims to increase productivity, reduce fuel costs and improve the quality of technological operations in plant production. Also, a science-based approach to the choice of composition of the unit makes it possible to reduce labor costs and increase the technical and economic efficiency of the use of machine-tractor units. In many cases, the speed determined by the tractor's energy saturation cannot be realized due to agro-technological or physiological constraints. Economic constraints on machine unit speed are due to changes in energy costs for the process, operational reliability of machines within the unit, and some deterioration in the use of change times. In each case, the speed modes should be specified taking into account the physical and mechanical properties of soils, the state of the field surface, the phases of plant development, soil moisture and other factors that affect the quality of work.

Compliance with the parameters of the unit, especially the production conditions - is a prerequisite for high performance of the unit. With the increase in the width of the grip of the unit proportionally increases its productivity, and for sowing machines, sprayers and a number of others - the quality of work is improved, due to the reduction of the area of the field exposed to the running systems, the number of butt rows decreases, the conditions of technological maintenance of the unit are improved and its maintenance.

Keywords: machine unit, justification, optimization, speed modes, methodology, performance.

\section{Вступ}

Висновок про правильність вибору того чи іншого складу агрегату необхідний 3 урахуванням маневрових характеристик трактора і кінематичних параметрів робочої машини. Значення коефіцієнтів зчеплення ведучого апарату 3 грунтом та опору перекочування для різних агрофонів відіграє важливу роль у процесі вибору швидкісного режиму роботи, що в свою чергу покликано збільшити продуктивність, зменшити витрати палива та підвищити якість виконання технологічних операцій в рослинництві.

Відповідність параметрів агрегату, перш за все виробничим умовам - $є$ передумовою високої продуктивності агрегату. Із збільшенням ширини захвату агрегату пропорційно підвищується його продуктивність, а для посівних машин, обприскувачів і ряду інших підвищується якість виконання роботи, внаслідок зменшення площі поля яка піддається дії ходових систем, зменшується кількість стикових міжрядь, поліпшуються умови технологічного обслуговування агрегату і скорочується кількість персоналу по його обслуговуванню.

\section{Постановка проблеми}

Правильно скомплектований агрегат має задовольняти вимоги агротехніки, забезпечувати раціональне використання машин з найвищою продуктивністю і найменшою витратою палива й мастильних матеріалів, а отже, найменшою вартістю роботи.

\section{Аналіз останніх досліджень}

Зростання технологічних вимог до технологічних процесів аграрного виробництва супроводжується формуванням нових складів і комплексів технологічних машин. В умовах світової конкуренції на ринку технічних засобів України все більше розвивається сегмент імпортної нової та вживаної сільськогосподарської техніки. Такі тенденції викликані вимогами ринку, щодо виробництва конкурентоспроможної сільськогосподарської 
продукції. Ринок імпортної сільськогосподарської техніки все більше забезпечує аграрне виробництво необхідними технічними засобами для впровадження передових сучасних технологій. Вітчизняне сільськогосподарське машинобудування поступово втрачає свої позиції на ринку технічних засобів, а сільськогосподарська техніка за технічними характеристиками та якістю виготовлення в більшості випадків спроможна конкурувати із зарубіжною.

Такий стан технічного забезпечення потребує комплексного його аналізу стану та тенденцій розвитку з врахуванням питань наукового, інженерно-технічного, організаційноекономічного, правового та соціального характеру.

У зв'язку зі змінами у аграрному виробництві відбулися значні зміни у формуванні та складі машинно-тракторних парків господарств нашої держави. Агропромислове виробництво України потребує технологічного оновлення ефективними, енергозберігаючими та надійними технічними засобами. Для сталого функціонування повноцінного парку технічних засобів необхідно дотримуватися принципів раціонального та ефективного використання ресурсів $[14,15]$.

\section{Мета досліджень} агрегату.

Формування методики обгрунтування раціонального складу i режиму роботи

Для обгрунтування складу агрегату необхідно знати експлуатаційні властивості енергетичного засобу, сільськогосподарських машин, а також умови їх роботи.

\section{Результати досліджень}

У роботі розроблено методику, яка дає можливість визначити раціональний склад $\mathrm{i}$ режими роботи машинних агрегатів.

Нижче наведено теоретичні положення комплектування машинних агрегатів $[1,2]$.

Перш за все визначаємо експлуатаційні показники енергетичного засобу в певних умовах роботи.

Дотична сила тяги трактора за можливостями двигуна дорівнює, кН:

$$
P_{\kappa}=\frac{3,6 N_{H} \cdot \eta_{M 2}}{V_{g}},
$$

де $P_{k}$ - дотична сила тяги, кН;

$N_{H}$ - номінальна потужність двигуна, кВт;

$H_{\text {мг }}$ - коефіцієнт корисної дії трансмісії;

$V_{g}$ - допустима робоча швидкість агрегату, км/год.

Для збиральних агрегатів, які обмолочують або подрібнюють продукцію, максимальна допустима робоча швидкість руху за умов оптимального завантаження машини по пропускній здатності визначається за виразом:

$$
V_{g}=\frac{3,6 \cdot g_{\phi}}{B_{p} \cdot Q}, \kappa м / \text { год }
$$

де $g_{\phi}-$ пропускна здатність машини, кг/с;

$B_{p}$ - робоча ширина захвату машини, м;

$Q$ - урожайність продукції, т/га.

У випадках агрегатування тягово-приводної машини потужність двигуна, яка витрачається на тягу $N_{m}$, дорівнює:

$$
N_{T}=N_{H}-N_{B в \Pi, \kappa B m,}
$$

де $N_{B в \Pi}-$ потужність, яка витрачається на привід робочих органів машини, кВт. 
Одержане значення $N_{T}$ для даного енергетичного засобу підставляється у формулу (1) замість $N_{H}$.

У зв'язку з тим, що рушійна сила обмежується силою зчеплення ведучого апарата 3 грунтом, ії значення можна визначити:

$$
F_{\max }=G_{m p} \cdot g \cdot \mu \cdot \varphi, \kappa H,
$$

де $F_{\max }$ - максимальна сила зчеплення ведучого апарата 3 грунтом, кН; $G_{m p}$ - маса енергетичного засобу, т; $g$ - прискорення вільного падіння, м/ $\mathrm{c}^{2} ; \varphi-$ коефіцієнт, який враховує розподіл маси енергетичного засобу на ведучий апарат; $\mu$ - коефіцієнт зчеплення ведучого апарата $з$ грунтом (табл. 1).

Коефіцієнт $\mu$ залежить від агрофону поля i класу грунтів, на якому працює грунтообробний агрегат, та від типу рушія. 3 достатньою точністю цей показник можна визначити за такими залежностями,

- для енергетичних засобів з гусеничними рушіями;

$$
\mu=0,9867-0,3289 \cdot \ln (\psi)+0,02 \cdot \rho ;
$$

- для енергетичних засобів на пневматичних шинах:

$$
\mu=1,1428-0,2402 \cdot \ln (\psi)+0,02 \cdot \rho ;
$$
опором.

де $\psi$ - агрофон поля, на якому працює машинний агрегат; $\rho$ - клас грунту за питомим

Таблиця 1

Значення коефіціснтів зчеплення ведучого апарату з грунтом та опору перекочування для різних агрофонів

\begin{tabular}{|c|c|c|c|c|c|}
\hline \multirow{2}{*}{ Фон } & \multirow{2}{*}{ Шифр } & \multicolumn{2}{|c|}{ Колісні } & \multicolumn{2}{c|}{ Гусеничні } \\
\cline { 3 - 6 } & & $\mu$ & $f$ & $\mu$ & $f$ \\
\hline $\begin{array}{c}\text { Дорога з твердим } \\
\text { покриттям }\end{array}$ & 1 & 0,90 & 0,02 & 1,00 & 0,05 \\
\hline Грунтова дорога & 2 & 0,82 & 0,04 & 0,97 & 0,07 \\
\hline Суха стерня & 3 & 0,77 & 0,07 & 0,93 & 0,08 \\
\hline Волога стерня & 4 & 0,65 & 0,10 & 0,90 & 0,09 \\
\hline Злежана оранка & 5 & 0,60 & 0,12 & 0,80 & 0,10 \\
\hline Поле під сівбу & 6 & 0,55 & 0,16 & 0,75 & 0,12 \\
\hline Свіжа оранка & 7 & 0,50 & 0,20 & 0,65 & 0,14 \\
\hline Вологий луг & 8 & 0,45 & 0,22 & 0,60 & 0,16 \\
\hline Болото, сніг & 9 & 0,30 & 0,24 & 0,50 & 0,18 \\
\hline
\end{tabular}

За питомим опором (кН/м²) грунти поділяють на 9 класів: I - 27...34; II - 35...39;

III - 40...48; IV - 49...55; V - 56...62;

VI - 63...67; VII - 68...75; VIII - 76...82;

IX $-83 \ldots 90$.

Рушійна сила агрегату $P_{\partial в}$ чисельно дорівнює:

- за умови, що $P_{\kappa}>F_{\max }, P_{\partial в}=F_{\max }$;

- за умови, що $P_{\kappa} \leq F_{\max }, P_{\partial \varepsilon}=P_{\kappa}$.

Основні сили опору руху енергетичних засобів можна визначити:

$$
P_{c}=G_{m p}(f \pm \sin \alpha)
$$

де $f$ - коефіцієнт опору перекочування;

$\alpha$ - нахил місцевості, град.

Коефіцієнт опору перекочування енергетичних засобів: 
- 3 гусеничним рушієм можна визначити з виразу:

$$
f=0,0413 \cdot \exp (0,1832 \cdot \psi)-0,002 \cdot \rho,
$$

- для енергетичних засобів з колісними рушіями:

$$
f=0,0277 \cdot \exp (0,2854 \cdot \psi)-0,002 \cdot \rho,
$$

Зусилля на гаку, яке розвиває енергетичний засіб, буде дорівнювати, кН:

$$
P_{\text {гак }}=P_{д в}-P_{C},
$$

У випадку перевищення розрахункового для даних умов зусилля на гаку над максимально допустимим, приймається, кН:

$$
P_{\text {гак }}=P_{\text {гак }}^{\prime},
$$

де $P^{\prime}$ гак - допустиме зусилля на гаку енергетичного засобу, $\kappa H$.

У залежності від призначення машини-знаряддя робочий опір, створюваний при виконанні технологічної операції, можна визначити:

- для плугів і лемішних лущильників, кН:

$$
R=k_{0 V} \cdot b \cdot a \cdot n_{K}+G_{m} \cdot g \cdot c \cdot(f \cdot \lambda \pm \sin \alpha),
$$

- для звичайних тягових машин, кН:

$$
R=k_{V} \cdot B+G_{m} \cdot g \cdot c \cdot(f \cdot \lambda \pm \sin \alpha),
$$

- для причіпних машин при відсутності тягового опору, кН:

$$
R=G_{m} \cdot g \cdot(f \pm \sin \alpha),
$$

- для транспортних агрегатів, кН:

$$
R=\left(G_{m}+\frac{G_{\text {ван }}}{2}\right) \cdot g \cdot(f \pm \sin \alpha),
$$

де $R$ - загальний опір машини, кН;

$k_{o v}$ - питомий опір плугів, кН/ $\mathrm{m}^{2}$;

$k_{v}$ - питомий опір звичайних машин, кН/м;

$b$ - ширина захвату корпуса плуга, м;

$a$ - глибина оранки, м;

$B$ - конструктивна ширина захвату звичайних машин, м;

$G_{m}$ - маса машини, т;

$G_{\text {ван }}$ - маса вантажу, що перевозиться, т;

$\lambda$ - коефіцієнт, що враховує довантаження енергетичного засобу.

Питомий опір машин-знарядь залежить від швидкісного режиму роботи і може бути уточнений за такими емпіричними залежностями:

- для плугів і лемішних лущильників, кН/ $\mathrm{M}^{2}$ :

$$
k_{0 V}=k_{0} \cdot\left[1+0,006 \cdot\left(V_{P}^{2}-V_{0}^{2}\right)\right],
$$

- для інших машин, кН/м:

$$
k_{V}=k \cdot\left[1+T \cdot\left(V_{P}-V_{0}\right)\right], ;
$$

де $k_{o}$ - питомий опір плугів при швидкості руху до 5 км/год, кН/м²; $V_{p}$ - робоча швидкість агрегату, км/год; $V_{o}$ - швидкість, при якій визначено питомий опір машин у

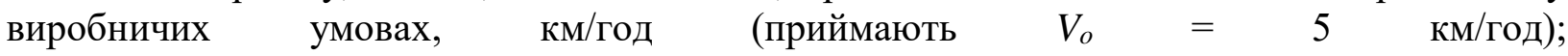
$k$ - питомий опір звичайних машин при швидкості до 5 км/год, кН/м; $T$ - темп приросту питомого опору для відповідної машини.

Таким чином, знайшовши зусилля на гаку енергетичного засобу, а також загальний опір грунтообробних машин-знарядь, можна визначити необхідну їх кількість у агрегаті.

Для багатомашинних агрегатів необхідно спочатку визначити можливу ширину захвату машинного агрегату, м: 


$$
B_{m}=\frac{P_{\text {гак }}}{\sum_{\xi=1} \frac{R_{\xi}}{B_{\xi}}},
$$

Тоді кількість машин кожного типу у агрегаті дорівнює:

$$
Z=\text { int } \stackrel{\Theta}{\xi}\left(\frac{B_{m}}{B_{\xi}}\right),
$$

де $B_{m}$ - максимальна теоретична ширина захвату агрегату, м;

$R_{\xi}$ - опір машини $\xi$-того типу, кН;

$B_{\xi}$ - конструктивна ширина захвату машини $\xi$-того типу, $\mu$.

Загальний опір машин у агрегаті визначається за виразом, кН:

$$
\underset{\xi=1}{R_{a}}=\sum z_{\xi} \cdot R_{\xi}
$$

За умови, що $R_{a}>P_{\kappa p}$ проводиться корегування тягових показників енергетичних засобів на швидкісному режимі $V_{g}^{\prime}=V_{g}-\Delta V$ до моменту, при якому буде справедлива нерівність $P_{K P}>R_{a}$, і поточне значення швидкості $V_{д}$ не буде виходити за нижні межі допустимої для даного агрегату за агротехнічними вимогами.

Робоча швидкість агрегату 3 урахуванням буксування рушіїв визначається залежністю, км/год:

$$
V_{P}=V_{g}^{\prime} \cdot\left(1-\frac{\delta}{100}\right)
$$

де $V_{p}$ - робоча швидкість агрегату, км/год;

$\delta-$ буксування рушіїв, \%.

Буксування рушіїв енергетичних засобів обумовлюється загальним опором причіпної частини машинного агрегату і максимальною силою зчеплення ведучого апарата з грунтом. 3 метою визначення величини буксування введено поняття показника відносної сили тяги $\rho_{T}$ :

$$
\rho_{T}=\frac{R}{F_{\max }},
$$

Знаючи значення $\rho_{T}$, величину буксування визначають за такими рівняннями:

- для колісних тракторів:

$$
\begin{aligned}
& \delta_{K}=2,75+12,5 \cdot \rho_{T}+ \\
& +100 \cdot\left(\rho_{T}-0,10\right)^{6}
\end{aligned}
$$

- для гусеничних тракторів:

$$
\begin{aligned}
& \delta_{K}=0,15+4,00 \cdot \rho_{T}+ \\
& +100 \cdot\left(\rho_{T}-0,15\right)^{6} ;
\end{aligned}
$$

Таким чином, використавши наведені вище аналітичні залежності, є можливість розрахувати раціональний склад і швидкісний режим роботи машинних агрегатів. [3-13].

\section{Висновки}

Наведена методика дає змогу виконати розрахунок раціонального складу та швидкісного режиму роботи машинних агрегатів. Ця методика являє собою вихідні данні до розрахунку продуктивності агрегату, а у подальшому дає можливість визначити норми 
виробітку, витрати палива та вартість виконання механізованих робіт у рослинництві, використовуючи наявний позитивний досвід.

\section{Список використаних джерел}

1. Войтюк Д.Г., Мельник И.И., Гречкосей В.Д. Оптимизация комплексов машин и структуры МТП с применением ЭВМ. --К.: Печатный участок УПК УСХА, 1986. - 62 с.

2. Мельник I.I., Гречкосій В.Д., Бондар C.М. та ін. Оптимізація комплексів машин і структури машинного парку та планування технічного сервісу. - К.: Видавничий центр НАУ, $2004-54$ c.

3. Мельник I.I., Гречкосій В.Д., Надточій О.В., Марченко В.В. Технологічні комплекси машин для виробництва цукрових буряків та їх економічна ефективність / Збірник наукових праць НАУ, 2000, том VIII.

4. Мельник I.I., Гречкосій В.Д., Бондар C.М. Обгрунтування комплексів машин та нормативів потреби в техніці для рослинництва господарств різних організаційних форм зони Лісостепу України. Заключний звіт по госпдоговірній темі. Номер державної реєстрації 0100U002 341. Науковий звіт, 2002.

5. Мельник I.I., Гречкосій В.Д., Марченко В.В. Технологічні комплекси машин для виробництва сої та їх економічна ефективність / Зб. Наукових праць НАУ, 2003, том 15.

6. Мельник I.I., Гречкосій В.Д., Марченко В.В. Комплексна механізація виробництва озимого ріпаку / Пропозиція, 2004, № 2 і 3

7. Мельник I.І., Гречкосій В.Д., Марченко В.В. Комплексна механізація виробництва сої / Пропозиція, 2004, № 5.

8. Мельник I.I., Гречкосій В.Д., Марченко В.В. Комплексна механізація виробництва соняшнику / Пропозиція, 2004, № 11.

9. Карабаницкий А.П. Комплектование энергосберегающих машиннотракторных агрегатов: Учеб. пособие / А.П. Карабаницкий, М.И. Чеботарев. - Краснодар: КубГАУ, 2012. - 97 с.

10. Мельник I.I., Гречкосій В.Д., Гаврилюк Г.Р., Шатров Р.В. Ефективність механізованого виробництва ярої пшениці /Агроном, 2005, № 2.

11. Мельник I.I., Гречкосій В.Д. Механізоване виробництво картоплі / Агроном, $2005,4$.

12. Мельник I.І., Гречкосій В.Д. Комплекси машин для вирощування та збирання трав на сіно і сінаж / Агроном, 2006, № 5.

13. Мельник I.I., Гречкосій В.Д. Прогресивні механізовані технології в рослинництві / Електротехніка і механіка, 2006, № 1.

14. Саржанов О.А. Обгрунтування складу машинних агрегатів для виконання механізованих технологічних процесів у рослинництві на основі сучасних технічних засобів / О.А. Саржанов, О.В. Таценко // Вісник Сумського національного аграрного університету. Серія : Механізація та автоматизація виробничих процесів. - 2015. - Вип. 11. - C. 39-45. - Режим доступу: http://nbuv.gov.ua/UJRN/Vsna_mekh_2015_11_10

\section{Reference}

1. Voityuk DG, Melnik II, Grechkosey V.D. Optimization of machine complexes and MTP structure using computers. $-\mathrm{K} .:$ The printing section of the Criminal Procedure Code of the Ukrainian Academy of Agricultural Sciences, 1986.

2. Miller I.I., Grechkosiy V.D., Bondar S.M. that in. Optimization of the complex of machines and the structure of the machine park and the planning of the technical service. - K .: Vidavnichy center of NAU, 2004 - 54 p. 
3. Miller I.I., Grechkosiy V.D., Nadtochiy O.V., Marchenko V.V. Technological Complexes of Machines for Virology of Chicken Worms and their Economic Effectiveness / Zbirnik Naukovykh Prats NAU, 2000, Volume VIII.

4. Miller I.I., Grechkosiy V.D., Bondar S.M. Obgruntuvannya complex of machines and standards for technical consumption for the growth of state thanks to the state organizations of the forms of the zone Lisostepu Ukraine. The conclusion is called on state themes. State registration number 0100U002 341. Naukovy Zvit, 2002.

5. Miller I.I., Grechkosiy V.D., Marchenko V.V. Technological complexes of machines for virobility technology and economic efficiency / Зб. Science Prac NAU, 2003, Volume 15.

6. Miller I.I., Grechkosiy V.D., Marchenko V.V. Complex mechanization of winter winter production / Proposition, 2004, No. 2 and 3

7. Miller I.I., Grechkosiy V.D., Marchenko V.V. Complex mechanization of virology cooperation / Proposition, 2004, No. 5.

8. Miller I.I., Grechkosiy V.D., Marchenko V.V. Complex mechanization of virobnosis to the sleepyhead / Proposition, 2004, No. 11.

9. Karabanitsky A.P. Acquisition of energy-saving machine-tractor units: Textbook. allowance / A.P. Karabanitsky, M.I. Chebotarev. - Krasnodar: KubSAU, 2012 .-- 97 p.

10. Miller I.I., Grechkosiy V.D., Gavrilyuk G.R., Shatrov R.V. Efficiency of mechanized virology of spring wheat / Agronomist, 2005, No. 2.

11. Miller I.I., Grechkosiy V.D. Mechanization of the cartoper / Agronomist, 2005, 4.

12. Miller I.I., Grechkosiy V.D. Complexes of machines for viropuvannya and zbirannya herbs on sino and sinazh / Agronomist, 2006, No. 5

13. Miller I.I., Grechkosiy V.D. Progressive mechanical technology in roslinnitsvy / Electrical Engineering and Mechanics, 2006, No. 1.

14. Sarzhanov O.A. Obuuntuvannya warehouse of machine units for the weekend of mechanical technological processes in roslinnitsvy based on the most current technical concerns / O.A. Sarzhanov, O.V. Tatsenko // News of the Sumy National Agricultural University. Seriya: Mechanization and automation of virological processes. - 2015. - VIP. 11. - S. 39-45. - Access mode: http://nbuv.gov.ua/UJRN/Vsna_mekh_2015_11_10 